University for Business and Technology in Kosovo

UBT Knowledge Center

Oct 27th, 3:15 PM - 4:45 PM

\title{
Elements of sustainable architecture in vernacular architecture: The case of 19 th century urban dwellings of Kosovo
}

\author{
Arbër Sadiki \\ University for Business and Technology, arber.sadiki@ubt-uni.net \\ Arnia Kryeziu \\ University for Business and Technology, arnisa.kryeziu@ubt-uni.net
}

Follow this and additional works at: https://knowledgecenter.ubt-uni.net/conference

Part of the Architecture Commons

\section{Recommended Citation}

Sadiki, Arbër and Kryeziu, Arnia, "Elements of sustainable architecture in vernacular architecture: The case of 19 th century urban dwellings of Kosovo" (2018). UBT International Conference. 7.

https://knowledgecenter.ubt-uni.net/conference/2018/all-events/7

This Event is brought to you for free and open access by the Publication and Journals at UBT Knowledge Center. It has been accepted for inclusion in UBT International Conference by an authorized administrator of UBT Knowledge Center. For more information, please contact knowledge.center@ubt-uni.net. 


\title{
Elements of sustainable architecture in vernacular architecture: The case of $18^{\text {th }}$ and $19^{\text {th }}$ century urban dwellings of Kosovo.
}

\author{
Arbër Sadiki $^{1} \quad$ Arnisa Kryeziu $^{1}$ \\ ${ }^{1}$ UBT - Faculty of Architecture and Spatial Planning; \\ Lagjja Kalabria no. \#; Prishtina; KOSOVO http://ubt-uni.net/ \\ arber.sadiki@ubt-uni.net, arnisa.kryeziu@ubt-uni.net
}

\begin{abstract}
The paper presents a research on parameters of sustainable architecture identified in the vernacular architecture of Kosovo, specifically in the urban dwelling constructed during the $18^{\text {th }}$ and $19^{\text {th }}$ century. Main principles of sustainable architecture in general were initially evaluated and elaborated in order to identify and compare to the study cases included in this research. Analyzes have shown characteristic architectural elements of this typology such as: extended eaves, open end closed çardak (gallery) and qoshk (garret), window wooden shutters, natural building materials, vegetation and more, to be part of the conscious architectural design with sustainable approach. As conclusion, these models illustrate an excellent example of the contribution of traditional construction in improving sustainable architecture parameters, especially when taking into consideration the context, time and circumstances of their construction. Reinterpretation of traditional architectural elements was observed in various contemporary architecture examples. In this regard, these precedents are a great example of how the principles of sustainable architecture and sustainable approach in general, should not be considered as a "task" determined by today's energy and sustainable policies, but as a practicality and prudence of the man in co-existence with the nature.
\end{abstract}

Keywords: sustainable architecture, Kosovo vernacular architecture, urban dwelling, architectural elements, natural building materials;

\section{Introduction}

Vernacular architecture as a common human value built and inherited from generation to generation, without any doubt, represents one of the most comprehensive historical, cultural, economic and social developments of a society. In its great examples surviving present days, we can witness technological achievements through construction techniques, use of materials, intelligent approaches such as flexibility and sustainability, the development and appreciation of art and culture through decorative crafts, wall paintings and more and the overall cultural emancipation understood through functional and volumetric composition of the space. Impelled by these indisputable values, vernacular architecture has always been a topic of study and research for experts in order to identify, preserve and promote these cultural values. 
Aim of the study is to identify and analyze sustainable approach and architectural elements in vernacular architecture of $18^{\text {th }}$ and $19^{\text {th }}$ century urban dwelling of Kosovo, often known as banesa. In order to identify and compare this approach in the study cases chosen for research, general principles of sustainable architecture were primarily evaluated and elaborated.

Notwithstanding the lack of studies on vernacular architecture in Kosovo, some of its multidimensional values are already known and discussed by researchers. In this context, the contribution of "Albanian Tower (Kulla) of Dukagjini region" can be distinguished as one of the earliest forms of collective housing [5], the values of "Kosovo's urban dwelling of $18^{\text {th }}-19^{\text {th }}$ century" as one of the most developed building typology in the region in the functional, volumetric and aesthetic context [6], up to the original techniques of architectural and constructive systems latent in the urban dwellings [3].

Despite its bioclimatic powerful elements that contribute positively to the advancement of sustainable building parameters and principles, banesa is studied very little in this regard, therefore it remains an appealing topic for researchers of architectural heritage.

\section{General Parameters of Sustainable Architecture}

The attention of mankind in the use of natural recourses based on the location and climatic conditions, with the aim of creating high comfort living spaces, is noticed from the first forms of the environments that he constructed to shelter and cultivate his vital activities.

Since the $1^{\text {st }}$ century BC, the Roman writer, architect and engineer Vitruvius, considerers homes to be well planned if primarily the location, context and the climatic characteristics are taken into consideration [8].

Today, in the context of global sustainable development, the existence of policies and the possibility of measuring sustainable construction parameters has defined specific structures and forms regarding the evaluation of these parameters. LEED Leadership in Energy and Environmental Design, has built a structure under which each building is assessed through the following criteria:

- Water efficiency;

- $\quad$ Energy and Atmosphere;

- $\quad$ Materials and Resources;

- Indoor Environmental Quality;[1]

Fulfillment of these criteria directly affects the improvement of living comfort parameters such as: air quality, thermal and visual comfort and acoustics, free of harmful substances to the health of users.

Regardless of the extensive number of factors contributing to the creation of satisfying life comfort, regulation and conservation of accumulated energy inside the building can easily be considered as the main contributing factor. Equivalently important are the orientation of the building in interrelation with its location and climate characteristics, proximity between buildings, choice of adequate vegetation, construction material and more. The greater the perimeter of the surface is, the higher 
the possibility of losing energy with facility increase, therefore depending on the shape, a building with the same floor surface can have different perimeter surfaces and consequently different energy coefficient.

\section{The $18^{\text {th }}$ and $19^{\text {th }}$ Century Urban Dwelling of Kosovo in the Context of Sustainable Architecture}

Urban dwelling of Kosovo can widely be evaluated as smart architecture in both formal and principal aspect, when considering the efficiency using limitless natural sources of energy and material, flexibility, adaptability and luxuriousness.

\subsection{General Characteristics of banesa of $18^{\text {th }}$ and $19^{\text {th }}$ century}

In the towns of $18^{\text {th }}$ and $19^{\text {th }}$ century of Kosovo, a house (also known as banesa) represents the basic unit of urban configuration by which neighborhoods (mahale) as greater ensembles were formed. Unity of these (organic) neighborhoods created the city structure. The urban developed was created spontaneously, without any anticipating planning but always based on the context and necessities of the residents. As the most advanced and influential architectural urban element of the time, banesa shaped the overall urban development.

Admitting the great number of factors influencing the typological shaping of banesa, the most accurate classification could be done based on the main compositional element as follows:

- Dwellings with a porch (Banesa me hajat);

- Dwellings with an open/closed gallery (Banesa me çardak);

- Dwellings with garret (Banesa me qoshk);

- Urban tower (Kulla qytetare); [7]

Additionally, as a result of functional necessity and plot constraints or the growing requirements in terms of aesthetics, composition and space, led the emergence of additional sub typologies based on the position of the compositional element (porch, gallery or garret) in the facade and its enclosure. Study cases chosen for this research represent the most advanced examples remaining in present days Kosovo [6].

\subsection{Sustainable features of Ethnographic Museum (Emin Gjiku complex) in Prishtina}

Identified sustainable features of the Emin Gjiku museum in Prishtina are:

- Efficient, passive protection from strong solar rays during summer and obstruction of low angle solar rays during winter season through the extended eves; 
- Passive protection from sun through wooden window covers (shutters) with horizontal opening at different angles depending on the angle of sun rays;

- Reduction of accumulated energy loss as a result of the floor plan compactness by reducing to the maximum the perimeter of the building and volumetric difference of the spaces based on the seasonal use and their need to be heated;

- The positive impact of the open or closed gallery or garret as the transitional space between the external environment and the interior of the building representing quality, relaxing outdoor spaces, for all seasons;

- Use of circumstantial materials such as sun dried earth bricks (adobe bricks qerpiqë)as infill or masonry material, wood for floor and roof construction, backed terracotta tiles (qeremidja) for roof covering, have a positive impact on the maximum reduction of the energy needed for production as well as transportation of the materials to the construction site;

- All construction materials used are easily recycled with minimal energy required.

- Accumulation of rain water and well (ground water);

- Hot gasses from the cooking fireplace heat simultaneously the bath (hamamxhik);

A very distinctive architectural element we can witness in almost all cities of Kosovo is the extended eave. Apart from its compositional character and aesthetic purposes, it undoubtedly has a bioclimatic character too. This element is clearly expressed in the Emin Gjiku complex, with a depth of up to 2.85 meters, supported by diagonal beams (pajanta) as consequence of constructive support.

In order to determine the favorable bioclimatic characteristics of extended eaves, analysis of sun penetration during both winter and summer solstices have been carried out. As these graphical analysis illustrate, the extended eaves have a positive impact in creating a cozy ambiance by disabling the strong, direct sun rays during the summer while not hindering sunlight during winter, allowing the low angle rays to penetrate and heat naturally the premises of the building.
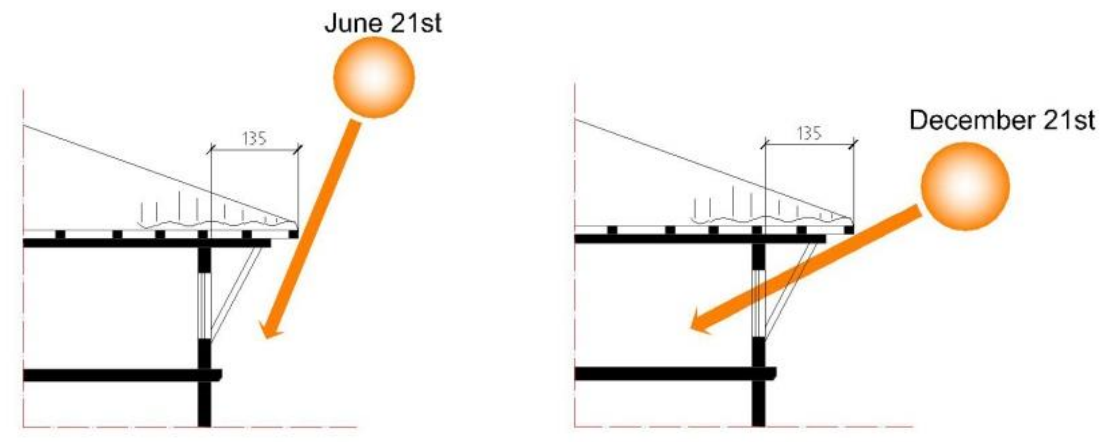

Figure 1. Analysis of the sun angle during summer and winter equinoxses in relation to the extended eave at the ethnographic Museum Emin Gjiku, Prishtina. 
Furthermore, extended eaves protected the façade surfaces from heavy rains protecting the construction material - adobe bricks, as knowingly sensitive to water absorption.

Akin to the extended eaves, window wooden shutters have a protective importance to control the excessive sunlight during hot seasons. The shutters open in the horizontal axis, with possibility of different angle adjustment to allow sun ray regulation.

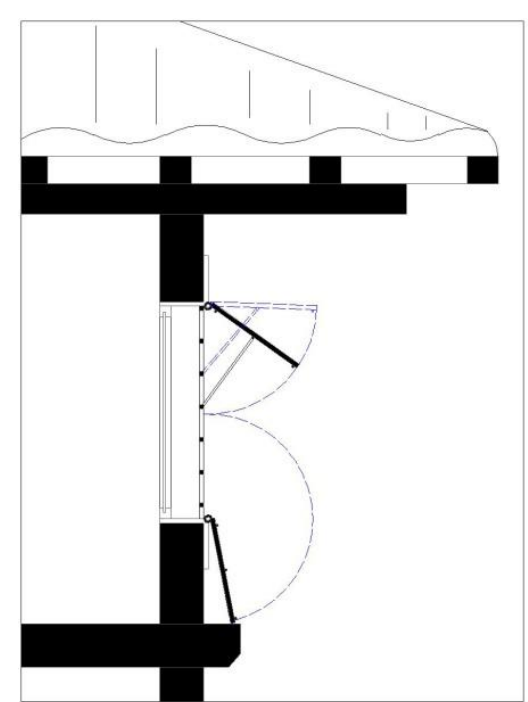

It is often discussed by many authors whether the role of wooden shutters is related to security or strictly bioclimatic. Characteristics such as the opening in horizontal axis, presence of the shutters on the first floor where the most important premises are located and the security is not an issue, strongly indicates that their character was essentially bioclimatic. This architectural element is widely found in this building typology among all urban centers of Kosovo and region, always in accordance with microclimatic needs related to location.

Figure 2. A detail of the opening of

the window shutters on different angles. The Ethnographic

Museum, Emin Gjiku, Prishtina, beginning of $19^{\text {th }}$ centry.

\subsection{Sustainable features of Ethnographic Museum in Gjakova}

Identified sustainable features of the Ethnographic Museum building in Gjakova are:

- Positive characteristics of the passive house using garret (located in east and south) to accumulate energy during cold seasons;

- Air circulation (natural ventilation) throughout the interior spaces contributing to the air quality parameters;

- Elimination of roof overheat by extracting warm air from the dorm vent installed on the roof.

- Use of circumstantial materials such as sun dried earth bricks (adobe bricks qerpiqë)as infill or masonry material, wood for floor and roof construction, backed terracotta tiles (qeremidja) for roof covering and organic additives have a positive impact on the maximum reduction of the energy needed for production as well as transportation of the materials to the construction site; 
- All construction materials used are easily recycled with minimal energy required.

- Hot gasses from the cooking fireplace were used to heat simultaneously the bath (hamamxhik) and rooms;

- $\quad$ Stone and thick wall mass used to refrigerate the space as storage for the goods sold by the family involved in the commerce of foodstuffs;

The gallery and the garret as forming elements of the banesa, on the basis of their position in the façade, may appear to be lateral, central and frontal as well as in some cases enclosed or open [6]. In the functional sense this compositional element was used as common area where the stairs connect the two stories and other residential spaces meet, forming a lovely summer environment especially in cases when opened. This architectural attitude, the open garret or gallery as well as porch reinforced the connection of human and nature.

Besides their functional importance, considering their usual positioning on the southern or southeastern part of the building, with an array of windows along the entire perimeter increasing the maximum access of light within it, constructs a logical argument for their bioclimatic character. This approach of considering the relation of the building and its location (climate) can be easily distinguished in the Ethnographic Museum of Gjakova (former dwelling), where both closed garrets (positioned in east and south) can collect sunlight throughout the entire day. As figure 3 illustrates, the accumulated heat from the southern and eastern garret, controlled by a door, can be distributed throughout the central corridor and other interor spaces. On the other hand, during summer time by closing the door in the garret, the undesired energy from the garret will be entraped.
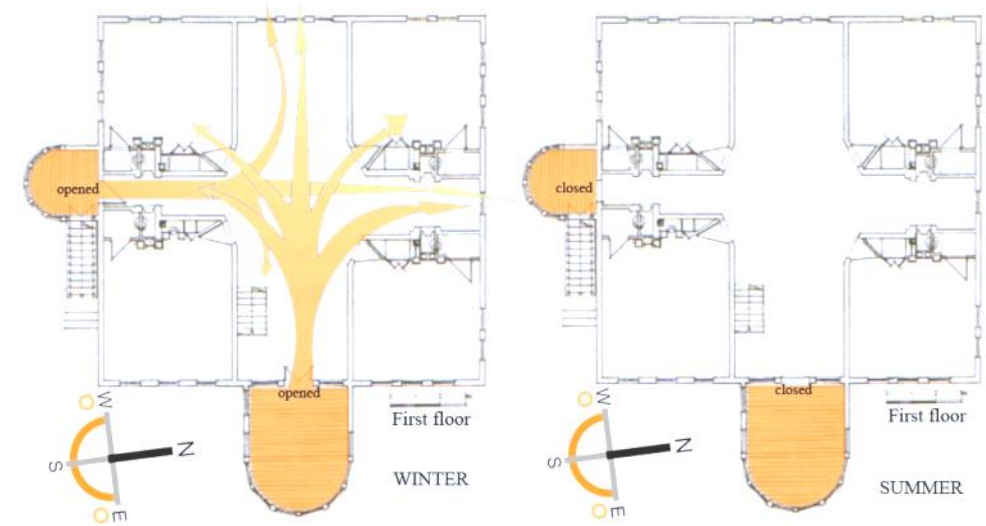

Figure 3. Performance of garret as energy acumulators during winter and summer season at the Ethnographic Musem of Gjakova.

Additionally, due to its plan composition, this building provides good ventilation and lighting. The two corridors stretching east-west and north-south, with openings in four sides of the cross, can circulate the air and create wind drafts, significantly raising the air comfort and illumination of the space. 


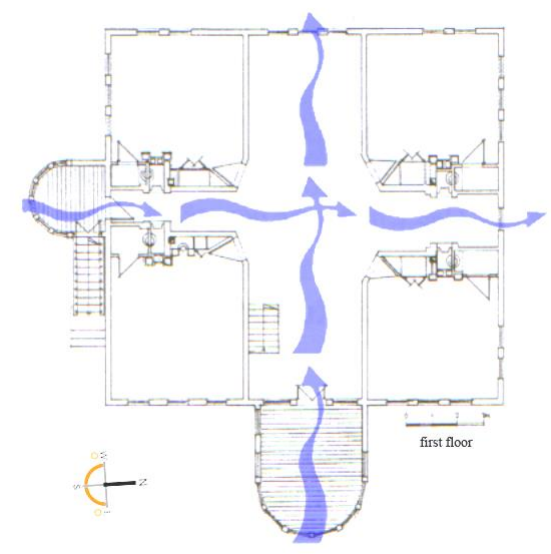

Figure 4. Ventilation flow at the house

with garret, the Ethnographic Museum of Gjakova.

Widely used materials in urban dwellings of $18^{\text {th }}$ and $19^{\text {th }}$ century are the soil-based materials, with their indisputable bioclimatic features. Soil can be found used differently along the building. For instance, previously molded, rectangular sun dried bricks were used as masonry or brick infill in the wooden skeleton construction. In the compressed form, soil was used as sound and thermal isolator in the floor construction, especially on the ground floor while when mixed with straw fiber as an addition for binding capabilities, it was used for plastering. Soil based construction materials have good thermal insulation capability, are resistant to burning, good regulators of moisture and above all at the time when the building is no longer needed they return to their organic state without a need for additional energy and pollution to the nature whatsoever. Different form the materials used in their pure natural form, the semiprocessed materials such as lime, obtained by burning limestone in impromptu ovens, served as binding material. The process of baking clay in furnaces produced bricks and terracotta roof tiles.

The use of the correct vegetation as a contributing element in the formation of suitable microclimate life is known and mentioned by Turkish-Ottoman guide Evliya Çelebi, who had visited Kosovo in the $17^{\text {th }}$ century and speaks about the beautiful and rich gardens with variety of vegetation, throughout Kosovo [2]. Planting of deciduous trees on the southern and eastern side of the building provided shade during summer season as a result of the growing season of the tree and sun penetration during winter season when the tree would be stripped from the leaves. Moreover, almost every family would cultivate the grape plant stretching along the entire garden which during summer, the growing season for grapes, would create a very pleasant microclimatic environment.
Given the circumstances of a society without developed material trade, widely used
construction materials in the entire territory of Kosovo were local materials such as: stone,

resistance to atmospheric agents, was commonly used for the foundations of buildings and in some
cases external constructive walls. Almost exclusively, bearing walls are accompanied by of improving elastic performance of the wall, documenting the seismic knowledge of the nature, stone represents a material with excellent
nath heat accumulation properties but relatively poor isolation [4] ood, clay and lime. 


\section{Application of Sustainable Features of Vernacular Architecture in Contemporary Architecture}

Previous chapters clearly enlisted the sustainable approach and expression in the urban banesa of $18^{\text {th }}$ and $19^{\text {th }}$ century. Having in mind these technological values of the vernacular architecture, novel for the time of their construction until present days, many of these elements and principles have been reused in contemporary architecture with different materials and architectural accent.
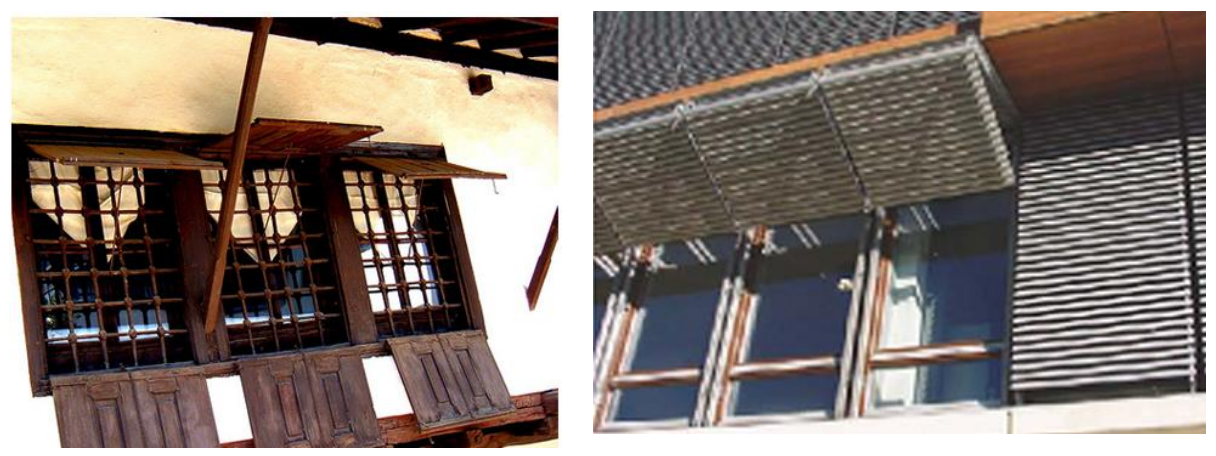

Figure 5. Similarity between the shutters of the Ethnographic Museum of Prishtina, early $19^{\text {th }}$ centery and Campeon Office building in Munich, arch Maier + Nueberger, $21^{\text {st }}$ century.

The formal and sustainable resemblence inbetween the urban dwelling of 18th and 19th century in Kosovo and Swiss passive house model illustrates the adaptation and reuse of spatial composition and architectural elements of the vernacular architecture in creating the ideal passive house.
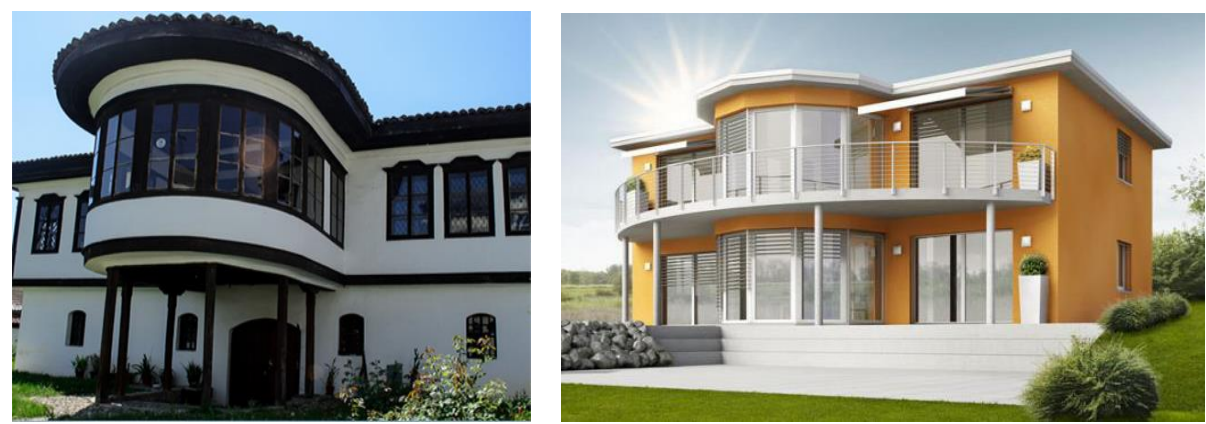

Figure 6. The similarity of dwelling with qoshk, the Ethnographic Museum of Gjakova and the Swiss passive house 


\section{Conclusion}

Based on the analysis of the urban dwellings of $18^{\text {th }}$ and $19^{\text {th }}$ century, carried with the focus on principles of sustainable architecture, one can identify a great number of important architectural and technical elements contributing to the advancement of building bioclimatic parameters. Since analysis were carried in most representative examples of this building typology, the extracted characteristics can be employed for all dwellings belonging to the same typology and period of construction throughout the territory of Kosovo.

The solution of temperature and sun penetration control inside the building during different seasons by introducing extended eaves which interrupt direct sun rays during summer and allows sun rays during winter, the use of window shutters with horizontal opening adjustment depending on the angle of the sun's rays, the use of gallery and garret as heat accumulators during winter seasons and the possibility of retaining them during the summer, up to the use of natural materials with excellent bioclimatic features, recycling possibilities or return to their natural form without the need for additional power, without contaminating the environment, clearly declares an approach towards a smart and efficient architectural conscience of local masters of $18^{\text {th }}$ and $19^{\text {th }}$ century.

From invisible principles until formal elements of vernacular architecture have been often reused in the contemporary architecture. Even though, they appear to be reinterpreted with contemporary architectural expression and different material technology, the principles are purely derived from lessons of vernacular architecture.

Based on the abovementioned arguments, we can finally conclude that vernacular architecture in general and urban dwellings of Kosovo of $18^{\text {th }}$ and $19^{\text {th }}$ century in particular are exceptional lessons of the respect for principles of sustainable architecture and sustainable development in general, not as imposition from policies but as a natural practicality of harmonizing human activities with the natural habitat.

\section{References}

[1] Bauer M., Mosle P., Schwarz M., Green Building-Guidebook for Sustainable Architecture, Springer, London (2009)

[2] Çelebiu E., Në Shqipëri dhe viset fqinje: Kosovë, Mal i Zi, Ohër, 55, Tiranë (2008)

[3] Doli F., Shkolla kosovare e mjeshtrit popullor shqiptar, Zëri, Prishtinë (1993)

[4] Kosorić V., Ekološka kuća, Gradjevinka Knjiga, Beograd (2008)

[5] Knežević G., Višestambene zgrade, Tehnička knjiga, Zagreb (1984)

[6] Riza E., Banesa qytetare kosovare të shek. XVIII-XIX, Akademia e shkencave dhe e arteve e Kosovës, Prishtinë (2006)

[7] Riza E., "Kosovar Urban Dwellings of $18^{\text {th }}-19^{\text {th }}$ centuries and their classification", CHwB Kosovo Office Report series No. 15/2010, Prishtina, (2010) 84-99

[8] Vitruvje, Deset knjiga o arhitekturi, Gradjevinka knjiga, III izdanje, Beograd (2006) 